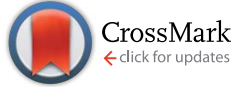

Cite this: RSC Adv., 2016, 6, 110146

Received 13th August 2016 Accepted 12th November 2016

DOI: $10.1039 / c 6 r a 20472 d$

www.rsc.org/advances

\section{Gold nanoparticle-assisted polymerase chain reaction: effects of surface ligands, nanoparticle shape and material $\dagger$}

\author{
Ekaterina Vanzha, ${ }^{a}$ Timofey Pylaev, ${ }^{a}$ Vitaly Khanadeev, ${ }^{a}$ Svetlana Konnova, ${ }^{\text {b }}$ \\ Valentina Fedorova ${ }^{\mathrm{b}}$ and Nikolai Khlebtsov*ac
}

Recent reports have shown significant improvement of the polymerase chain reaction (PCR) efficiency and specificity with the addition of gold nanoparticles (AuNPs). However, the underlying mechanisms are still unclear and debatable. Here, we report effects of AuNP concentration, shape, material, and surface functionalization on PCR outcome under typical amplification conditions. All nanoparticles were tested with two PCR diagnostic models: (1) the nitrogen fixation (NifD) gene from Azospirillum brasilense Sp7 bacteria and (2) the polymorphic ompA gene encoding major outer membrane protein of Chlamydia trachomatis. The optimal concentration of $16 \mathrm{~nm}$ citrate-stabilized negatively charged spherical AuNPs (zeta potential $-29.9 \mathrm{mV}$ ) was determined to be $0.4 \mathrm{nM}$, in agreement with previous data for quite different PCR systems. Functionalization with poly(vinylpyrrolidone) (PVP) and thiolated PEG (mPEG-SH) essentially did not change the zeta-potential $(-30 \mathrm{mV}$ and $-21 \mathrm{mV}$, respectively), but completely suppressed the PCR enhancement. Positively charged AuNPs with poly(diallyldimethylammonium) (PDDA) and cetyltrimethylammonium bromide (CTAB) capping polymers exhibited no specific enhancing effect on PCR or even inhibited the reaction at $5 \mathrm{pM}$ of AuNP-PDDA. Also, no specific PCR enhancement was obtained with CTAB-stabilized gold nanorods. To elucidate the role of the particle material, we performed PCR with gold and silica particles of comparable size and equal negative charges. In contrast to the great PCR enhancement with $16 \mathrm{~nm}$ AuNPs, $20 \mathrm{~nm}$ silica nanoparticles did not affect the PCR efficiency or inhibit the reaction at concentrations higher than $100 \mathrm{nM}$. These findings suggest that the nature of the PCR system components, surface stabilizing agents and the thermal conductivity of the nanoparticle material can play important roles in the nanoparticle-mediated PCR.

\section{Introduction}

The polymerase chain reaction (PCR) has become a standard biomolecular technique, which is commonly used for sensitive and rapid DNA detection. Exponential amplification of PCR allows replication of a single target copy to produce a large

${ }^{a}$ Institute of Biochemistry and Physiology of Plants and Microorganisms, Russian Academy of Sciences, 13 Prospekt Entuziastov, Saratov 410049, Russia. E-mail: khlebtsov@ibppm.ru

${ }^{b}$ Saratov Scientific and Research Veterinary Institute, Russian Academy of Agricultural Sciences, 6 Ulitsa 53 Strelkovoj Divizii, Saratov 410028, Russia

${ }^{c}$ Saratov National Research State University, 83 Ulitsa Astrakhanskaya, Saratov 410012, Russia

$\dagger$ Electronic supplementary information (ESI) available: Extinction spectra of as-prepared gold and silica nanoparticles; extinction spectra and photos of as-prepared and functionalized NPs before and after addition of $\mathrm{NaCl}$ salt; chemical structures and IUPAC names of surface ligands; evaluation of nano-PCR specificity and efficiency; the effect of AuNPs on PCR amplification of 710 bp target from A. brasilense and a 160 bp target from C. trachomatis, the effect of AuNPs-CTAB, AuNPs-PDDA and AuNRs-662 on PCR model 1; the effect of AuNPs on two-round PCR model 1; the effect of AuNPs on PCR amplification of a long 1156 bp target from PCR model 3. See DOI: 10.1039/c6ra20472d amount of DNA copies. ${ }^{1-3}$ However, the PCR can be error-prone and the specificity and efficiency of PCR can be unsatisfactory without proper optimization. ${ }^{4}$ As a result of the poor purification of template DNA, primer-template mismatches, spontaneous formation of primer dimers, and non-optimized PCRmixture ratio and thermocycling conditions, the formation of the target amplicon may be accompanied by non-specific side products called PCR artifacts. To fix this problem, several enhancers have been introduced: (1) various additives in PCR mixture, such as betaine, ${ }^{5}$ dithiothreitol, ${ }^{6}$ dimethyl sulfoxide, ${ }^{7}$ single-stranded DNA-binding protein $(\mathrm{SSB}) ;^{8}$ (2) instrumental design, including development of thermocyclers with precise heating/cooling rates; ${ }^{9,10}$ (3) optimization of PCR system through optimal $\mathrm{Mg}^{2+}$ concentration, cycle numbers and proper primer design: ${ }^{11-13}$ (4) enzyme modification; ${ }^{14,15}$ and (5) new touchdown ${ }^{16}$ and nested ${ }^{17}$ PCR strategies. Although these tools improve the PCR outcome, yet they are not all-purpose and the optimization protocol can be case dependent.

During the past decade, various nanomaterials have been used for PCR enhancement, including gold nanoparticles (AuNPs), ${ }^{18}$ silver nanoparticles and graphene oxide, ${ }^{19}$ reduced 
graphene oxide, ${ }^{19}$ titanium dioxide and quantum dots, ${ }^{20}$ upconversion nanoparticles, ${ }^{21}$ fullerenes $\left(\mathrm{C}_{60}\right),{ }^{22}$ carbon nanoparticles and nanotubes ${ }^{23}$ carbon nanopowder, ${ }^{24}$ magnetic nanoparticles, ${ }^{25}$ semiconductor nanomaterials, ${ }^{26,27}$ dendrimers, ${ }^{28}$ etc. Nevertheless, AuNPs are one of the promising candidates for use as PCR enhancers owing to their controlled geometrical parameters, reproducible synthesis and functionalization protocols. Recently, several hypothetic mechanisms of AuNP-assisted PCR were proposed to account for: (1) the SSBlike mechanism ${ }^{29}$ and electrostatic interactions between AuNPs and PCR components; ${ }^{30}$ (2) the high surface-to-volume ratio and non-specific adsorption of PCR components; ${ }^{28-31}$ and (3) the thermal properties of AuNPs. ${ }^{32}$ However, none of the suggested mechanisms can be considered convincing.

Here, we elucidated the role of the particle functionalization with neutral (PVP and mPEG-SH) and cationic (PDDA and $\mathrm{CTAB}$ ) polymer ligands and role of the nanoparticle material by performing PCR with gold and silica particles of comparable size and charge, other PCR conditions being unchanged. In addition, the nanoparticle shape effect was examined with CTAB stabilized nanorods. All nanoparticles were tested with two PCR diagnostic models: (1) the nitrogen fixation (NifD) gene from Azospirillum brasilense Sp7 bacteria; and (2) the polymorphic ompA gene encoding major outer membrane protein of Chlamydia trachomatis. At an optimal concentration of citratestabilized $16 \mathrm{~nm}$ negatively charged spherical AuNPs (0.4 nM), the PCR specificity and efficiency was greatly enhanced, whereas the negatively charged PVP- and PEG-stabilized AuNPs did not reveal any enhancing properties. Also, no specific PCR enhancement was observed with positively charged AuNPs and gold nanorods. By contrast to $16 \mathrm{~nm}$ negatively charged citratestabilized AuNPs, silica nanoparticles with the same charge and comparable $20 \mathrm{~nm}$ size have no impact on PCR efficiency. These observations show an important role of the nanoparticle material and surface modification in PCR enhancement, and could be helpful for further mechanistic studies.

\section{Results and discussion}

\subsection{Characterization of nanoparticles}

The following as-prepared and surface-functionalized AuNPs were used: negatively charged citrate-stabilized spherical gold nanoparticles (AuNP); nanoparticles capped with neutral polymers PVP and mPEG-SH (AuNP-PVP and AuNP-PEG-SH, respectively) and cationic polymers CTAB and PDDA (AuNPCTAB and AuNP-PDDA, respectively); gold nanorods (AuNR662, 662 stands for the longitudinal plasmon resonance maximum wavelength) with aspect ratio of about 2.3; and spherical silica nanoparticles $\left(\mathrm{SiO}_{2} \mathrm{NP}\right)$. The acronym definitions and chemical structures of polymeric ligands are given in ESI file (Section S1). $\dagger$ Fig. 1 shows illustrative TEM images of citrate-stabilized AuNPs, gold nanorods, and silica nanospheres. Extinction spectra of nanoparticles are shown in Fig. S1 (ESI). $\dagger$ Table 1 summarizes the values of the zetapotentials $\varsigma(\mathrm{mV})$, absorption maximum wavelengths of asprepared NPs in aqueous solution (for nanorods, the longitudinal resonance is indicated); the average TEM and DLS sizes; the nanoparticle molar concentrations normalized to the extinction $A_{\max }=1$; and the optimal concentrations and maximal specificity and efficiency of different PCR additives used in our PCR systems.

It follows from Table 1 that the average TEM and DLS diameters of citrate NPs $(16 \pm 0.8 \mathrm{~nm}$ and $17 \pm 1.2 \mathrm{~nm}$, respectively) have no significant difference within the standard deviation (SD) of about $1 \mathrm{~nm}$. By contrast, after functionalization with PVP, PEG-SH, CTAB, and PDDA polymeric ligands, the hydrodynamic diameters increase significantly by $6.8,10.4,3.6$, and $7.4 \mathrm{~nm}$. We consider these data as strong evidence for successful attachment of ligands. The second evidence comes from drastic change in colloidal stability of NPs before and after functionalization. Fig. S2 (ESI $\dagger$ ) shows extinction spectra and photos of citrate-stabilized and ligand-stabilized AuNPs before and after addition of $0.1 \mathrm{M} \mathrm{NaCl}$ salt. As expected, the addition of salt to the citrate-stabilized AuNPs results in immediate aggregation which is evident from changes in suspension color and extinction spectrum. By contrast, the addition of the same amount of salt to the ligand-stabilized AuNPs does not induce any aggregation phenomena accompanied by color and spectral changes. What is more, the ligand-stabilized NPs do not aggregate even in salt environment under strong temperature variations during PCR cycles (see below, Fig. 4).

\subsection{Mechanisms of AuNP enhancing effect}

Effect of nanoparticles on non-optimized PCR system was investigated by performing PCR with gold and silica particles of comparable size and charge, without changing the typical PCR
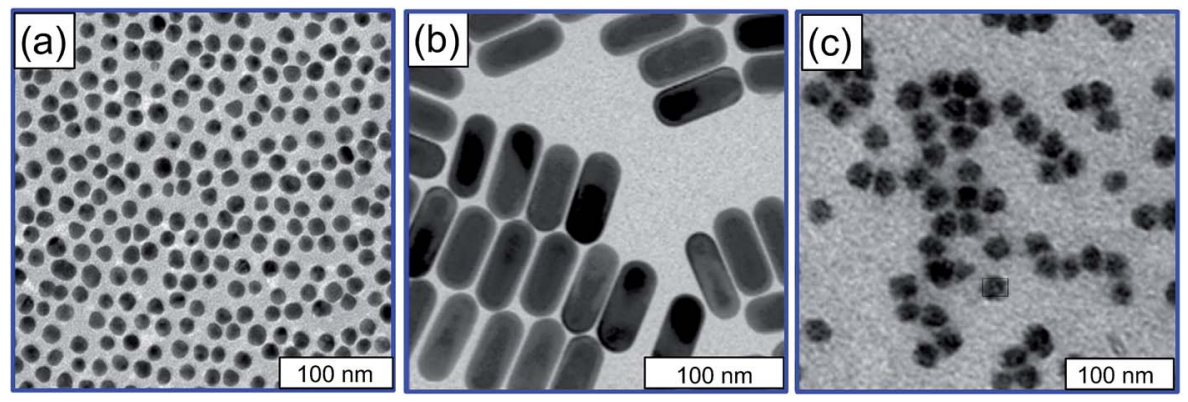

Fig. 1 Representative TEM images of as-prepared AuNPs (a), gold nanorods (b), and silica nanoparticles (c). 
Table 1 Parameters of nanoparticles used as additives in PCR systems

\begin{tabular}{|c|c|c|c|c|c|c|c|c|}
\hline Sample & $\begin{array}{l}\text { Zeta potential } \\
(\mathrm{mV})\end{array}$ & TEM size (nm) & $\begin{array}{l}\text { DLS size } \\
(\mathrm{nm})\end{array}$ & $\begin{array}{l}\lambda_{\max } \\
(\mathrm{nm})\end{array}$ & $\begin{array}{l}\text { Concentration } \\
\text { (nM) }\end{array}$ & $\begin{array}{l}\text { Optimal } \\
\text { concentration }\end{array}$ & $\begin{array}{l}\text { Maximal } \\
\text { efficiency }\end{array}$ & $\begin{array}{l}\text { Maximal } \\
\text { specificity }\end{array}$ \\
\hline AuNP & $-29.9 \pm 3$ & $16 \pm 0.8$ & $17.1 \pm 1.2$ & 520 & 4 & $0.4 \mathrm{nM}$ & $4.25 \pm 0.33$ & $5.7 \pm 0.43$ \\
\hline AuNP-PEG-SH & $-20.5 \pm 3$ & $16 \pm 1.0$ & $26.4 \pm 1.3$ & 522 & 4 & $4 \mathrm{nM}$ & $0.95 \pm 0.08$ & $1.09 \pm 0.12$ \\
\hline AuNP-CTAB & $+10.2 \pm 1$ & $25 \pm 1.2$ & $28.6 \pm 2.3$ & 524 & 4 & $1 \mathrm{fM}$ & $1.69 \pm 0.14$ & $1.03 \pm 0.14$ \\
\hline AuNP-PDDA & $+30.5 \pm 2$ & $16 \pm 1.0$ & $23.4 \pm 1.7$ & 522 & 2.8 & $1 \mathrm{fM}$ & $2.69 \pm 0.13$ & $1.5 \pm 0.11$ \\
\hline $\mathrm{SiO}_{2} \mathrm{NP}$ & $-31.2 \pm 3$ & - & $20.0 \pm 2.5$ & - & 490 & $1 \mathrm{nM}$ & $0.97 \pm 0.08$ & $1.07 \pm 0.12$ \\
\hline
\end{tabular}

conditions such as reagent concentrations and amplification profile.

To evaluate the overall ability of AuNPs to enhance PCR in terms of specificity and yield (efficiency), two PCR models were examined: (1) nitrogen fixation (NifD) gene from A. brasilense Sp7 bacterial culture (A. brasilense DNA detection, $710 \mathrm{bp}$ amplicon), and (2) chromosomal ompA gene of C. trachomatis (157 to $160 \mathrm{bp}$ target sequences for the variable domain 2 of MOMP). For brevity, we will refer to PCR models 1 and 2, respectively.

First, an optimal concentration of $16 \mathrm{~nm}$ citrate-stabilized AuNPs was found to be $0.4 \mathrm{nM}$ by adding AuNPs in various concentrations to both PCR systems (Fig. S3, ESI $\dagger$ ). This result is in good agreement with previous reports for quite different PCR models. ${ }^{29,32}$ Fig. 2a illustrates the specificity of AuNP-assisted PCR performed with model 1. Numerous nonspecific bands (smears) are observed for duplicate lanes 1 and 2 without nanoparticles, performed by using DNA template mixed with

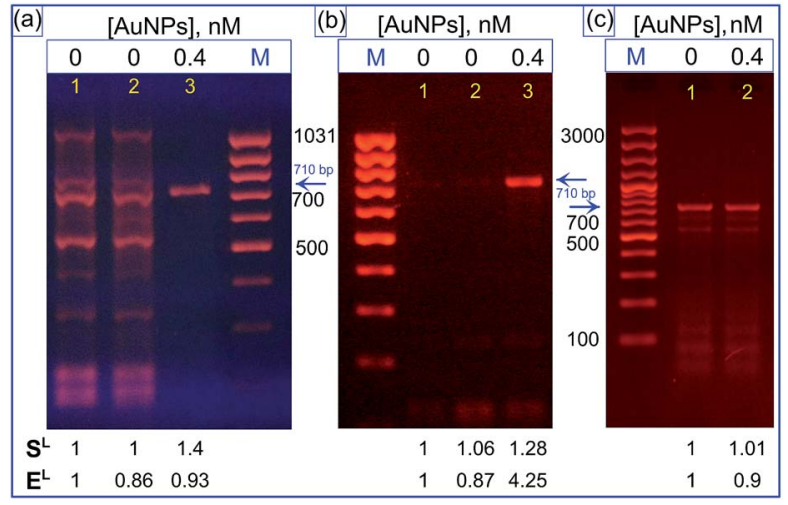

Fig. 2 Effect of citrate-stabilized AuNPs on PCR amplification of 710 bp region of NifD gene from A. brasilense Sp7 (model 1). Lanes M stand for DNA markers. (a) Illustration of the AuNP-assisted PCR specificity. The duplicate smeared lanes 1 and 2 were obtained without AuNPs, lane 3 corresponds to addition of $0.4 \mathrm{nM}$ AuNPs. (b) Illustration of the AuNP-assisted PCR high-yield efficiency. No significant bands were observed without AuNPs (duplicate lanes 1 and 2), whereas the addition of $0.4 \mathrm{nM}$ AuNPs results in clear detection of the target $710 \mathrm{bp}$ band. (c) Lanes 1 and 2 correspond to PCR without AuNPs and with AuNPs added after amplification step. The normalized quantities of PCR specificity $\left(S^{\llcorner}\right)$and efficiency $\left(E^{\llcorner}\right)$for each lane are indicated on the bottom panels. heterogeneous DNA fragments from similar microorganisms, whereas the addition of citrate-stabilized AuNPs at an optimal $0.4 \mathrm{nM}$ concentration completely inhibits all non-target bands. Fig. 2b exemplifies the efficiency of AuNP-assisted PCR, when no significant bands can be observed without nanoparticles (duplicate lanes 1 and 2) in the case of a low DNA template concentration, performed with ten-fold diluted initial template DNA. It should be emphasized, that even for this unoptimized system, the addition of AuNPs at optimal $0.4 \mathrm{nM}$ concentration results in a great PCR yield enhancement. To the best of our knowledge, this is the first demonstration of the yield-enhanced AuNP-PCR for A. brasilense Sp7 (NifD) gene. Additionally, we have observed the enhancing effect of AuNPs on two-round error-prone PCR system by taking the PCR product as a template for the second round of PCR amplification (Fig. S5, ESI $\uparrow$ ). Moreover, we have shown that AuNPs could be used to improve PCR specificity while amplifying the long PCR product (Fig. S6, ESI $\dagger$ ) which is in good agreement with a recent study by Zhou et al. ${ }^{33}$ Finally, in the third test with the model 1 (Fig. 2c), the AuNPs were added after amplification step to verify whether the AuNPs affect the amplification step themselves (as in Fig. 2a and b) or the post-amplification PCR outcome, just before gel electrophoresis. As shown on Fig. 2c, there was no effect of AuNPs added after amplification step without nanoparticles and the smeared nonspecific bands look similarly for lanes 1 and 2. This gives strong evidence for the first assumption citrate-stabilized AuNPs enhance the PCR outcome just during the amplification step.

One of hypothetic mechanisms of nano-PCR ${ }^{29}$ is that AuNPs exhibit SSB-like behavior related to greater affinity of singlestranded DNA-binding protein for ssDNA compared to dsDNA. However, this explanation remains unanswered the following question: how many AuNPs per one PCR tube are needed to perform efficient PCR amplification caused by an SSB-like moiety alone? Below we provide simple estimations based on our experimental conditions. A typical PCR mixture, used in our experiments with optimal concentration $0.4 \mathrm{nM}$ of AuNPs, ${ }^{29}$ contained $2.5 \mathrm{U}$ of Taq DNA-polymerase, equal to $10 \mathrm{ng}$ or $3.5 \mathrm{nM}$ of enzyme (the activity of $250000 \mathrm{U}$ Taq-DNA polymerase is equal to $4 \mathrm{ng}$ or $43 \mathrm{fmol}$ of $94 \mathrm{kDa} M_{\mathrm{w}}$ protein). A rough estimation shows that the molar ratio between Taq DNApolymerase and AuNPs is about $1: 10$. The number of DNA templates, which exponentially grows in each of 35 PCR cycles, 


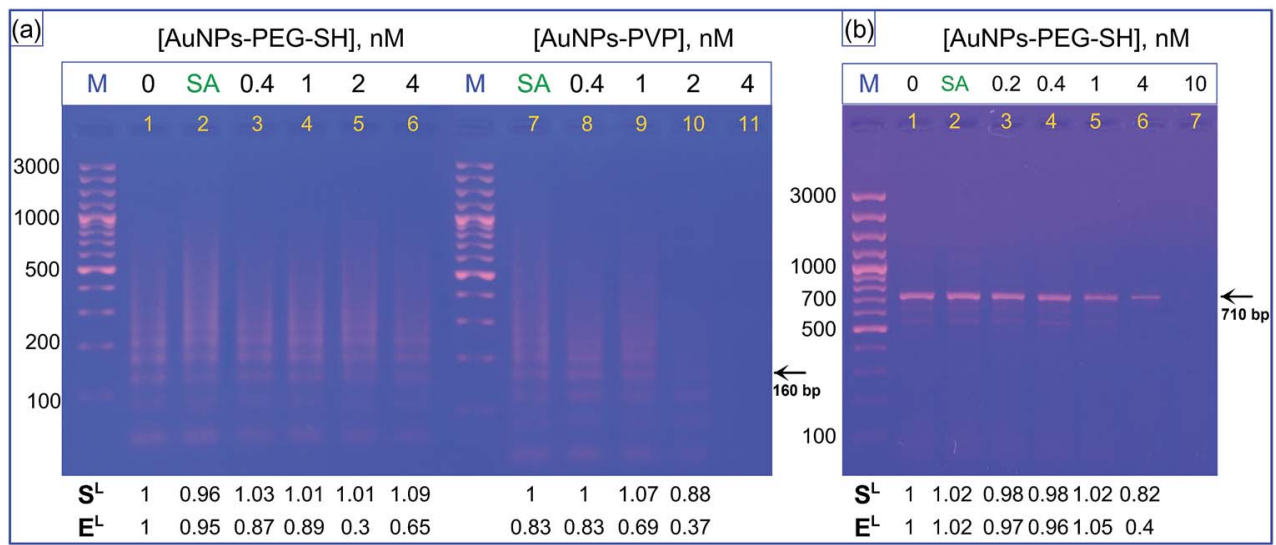

Fig. 3 (a). Effect of AuNPs capped with neutral polymers mPEG-SH and PVP on amplification of a 160 bp target from C. trachomatis. Symbols SA stand for addition of the capping polymers alone at a concentration corresponding to their concentration in $0.4 \mathrm{nM}$ AuNP solution, symbol M designates DNA markers. No specific enhancement was obtained for both polymers. (b) Effect of AuNP-PEG-SH particles on amplification of a $710 \mathrm{bp}$ target from A. brasilense Sp7 (model 1). With an increase in nanoparticle concentration, a gradual inhibition of all bands is observed, up to visual disappearance of the target band at $10 \mathrm{nM}$ concentration. The normalized quantities of PCR specificity $\left(S^{\mathrm{L}}\right)$ and efficiency $\left(E^{\llcorner}\right)$for each lane are indicated on the bottom panels.

is at least one order greater than the number of DNApolymerase molecules per one PCR tube. This means that the molar ratio DNA : AuNPs is about $1: 1$, which is quite insufficient to ensure AuNP action as an SSB-like substances. ${ }^{34}$ Consequently SSB-like behavior of gold nanoparticles seems to be not relevant to AuNP-assisted PCR enhancement.

To investigate a possible role of surface functionalization, we used AuNPs stabilized with two neutral polymer ligands such as PVP (AuNPs-PVP) and mPEG-SH (AuNPs-PEG-SH). According to Table 1 data, the both polymers do not change the sign and, in some extent, the value of nanoparticle zeta-potential. Surprisingly enough, the enhancing effect of AuNPs-PVP and AuNPsPEG-SH on PCR was negligible (Fig. 3).

In particular, non-specific bands were present even at high concentrations of nanoparticles, and the PCR tubes remained pink colored after amplification (Fig. 4). In some cases, the addition of a high nanoparticle amount resulted in complete inhibition of PCR (see, e.g., lanes 11 and 7 in Fig. 3a and b, respectively). We note that all these experiments included reagent controls with free polymers added to PCR tubes to verify the polymer effect alone (see lanes SA in Fig. 3). Thus, the functionalization of AuNP surface with neutral polymers, which does not change the initial negative charge of AuNPs, results in complete suppression of the PCR enhancement. This observation can be attributed to the steric hindrance for biomolecular

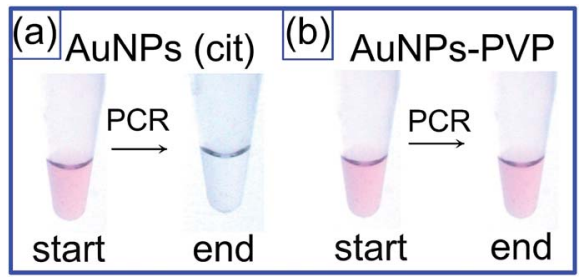

Fig. 4 Photos of test-tubes with citrate- (a) and PVP-stabilized (b) AuNPs before and after PCR amplification.
PCR components by protective PVP or mPEG-SH layers. In particular, these stabilizers prevent the nanoparticle aggregation after PCR amplification (Fig. 4b). By contrast, the stabilization of AuNPs with small citrate ions results in great enhancing PCR outcome (Fig. 2a and b), but does not prevent nanoparticle aggregation at the end of PCR (Fig. 4a).

The next set of experiments was aimed at understanding the role of AuNP functionalization with positively charged ligands. These experiments were motivated by a recent study, ${ }^{30}$ revealing a crucial role of the particle charge in PCR enhancing. Specifically, the optimal enhancing concentration of positivelycharged PDDA-capped AuNPs was $\operatorname{shown}^{30}$ to be $1.54 \mathrm{pM}$, which is 260 times lower than the optimal 400 pM concentration of negatively charged citrate-stabilized AuNPs. ${ }^{29}$ The goal of our experiment was twofold: $\left(^{1}\right)$ to verify the enhancing role of PDDA ligand for PCR models that differs from those investigated in ref. 30 ; (2) to examine the enhancing role of positive nanoparticle charge with CTAB ligand, which differs from PDDA. Clearly, the affirmative results for both points would expand the reported observations ${ }^{30}$ and confirm a universal role of the positive AuNP charge in PCR enhancing. However, our experiments with models 1 and 2 gave negative answers for both questions. Fig. 5a demonstrates the presence of non-target bands for very small $(0.001,0.01 \mathrm{pM})$ and high $(10,100 \mathrm{pM})$ concentrations of positively charged CTAB-stabilized AuNPs. Furthermore, for the same experimental model, no significant enhancement of PCR outcome was observed with PDDA-capped AuNPs (Fig. 5b) at variation of nanoparticle concentration from $0.001 \mathrm{pM}$ to $5 \mathrm{pM}$. Finally, when we used the positively charged CTAB-stabilized gold nanorods, the results were the same: no PCR enhancing or even complete inhibition. This illustrates insignificant role of the nanoparticle shape, at least for the PCR models examined here. Similar negative results were obtained for second PCR model, i.e. with nitrogen fixation (NifD) gene from A. brasilense Sp7 (Fig. S4, ESI $\dagger$ ). Thus, our experiments with two PCR models and with two cationic polymers did not 


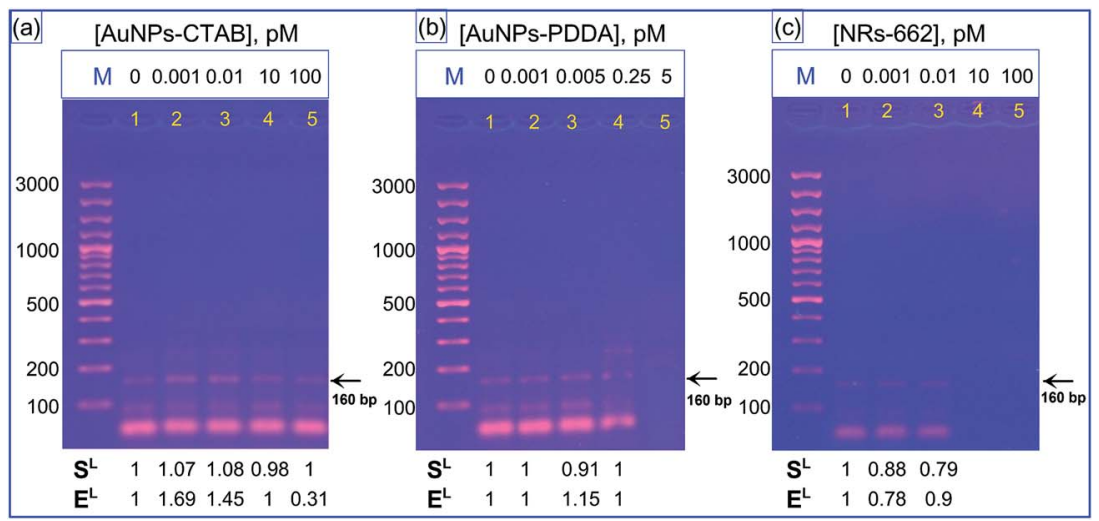

Fig. 5 Effect of AuNPs-CTAB (a), AuNPs-PDDA (b) and AuNRs-662 (c) on PCR amplification of a 160 bp target from model 2. The symbol M stands for DNA markers. Thus, the effect of ligand-capped AuNPs is not significant as compared with that for citrate-stabilized AuNPs. The normalized quantities of PCR specificity $\left(S^{\llcorner}\right)$and efficiency $\left(E^{\llcorner}\right)$for each lane are indicated on the bottom panels.

confirm any efficient PCR enhancing reported previously ${ }^{30}$ for a different PCR model and positively charged AuNPs with PDDA ligand.

The precise reasons for observed discrepancy between our results and previously reported ones are unclear at present. Furthermore, the observed effects at trace 0.001 AuNP concentrations cannot be explained in terms of existing mechanistic models. In any case, we can conclude that the enhancing role of positively charged AuNPs is not ubiquitous. Instead, it can be ligand-dependent and PCR model-dependent.

Another proposed mechanism of AuNP-assisted PCR is related to high thermal conductivity of AuNPs as compared to water. $^{32}$ This can change the amplification conditions in local environment around gold nanoparticles, thus changing the

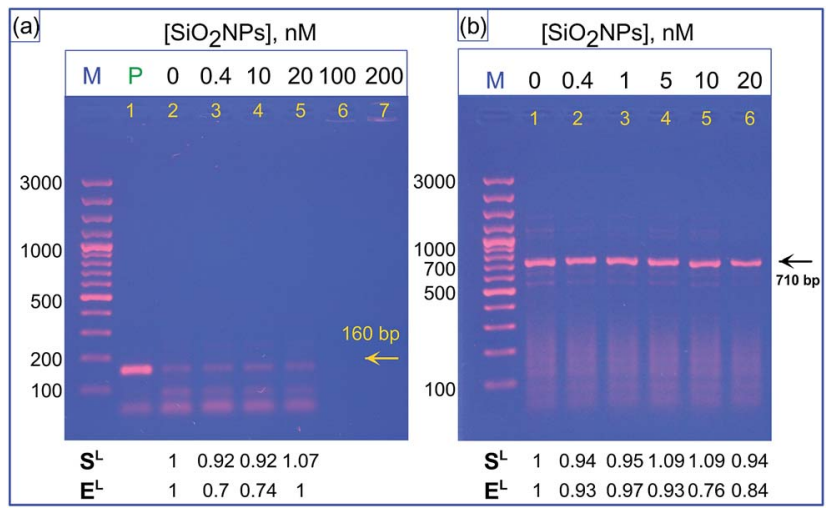

Fig. 6 (a) Effect of silica nanoparticles on amplification of a $160 \mathrm{bp}$ target from PCR model 2. The symbol M stands for DNA markers, the symbol $P$ designates a positive control with a purified DNA of genovar $\mathrm{E}$ as a template. No single distinct bands were observed at all nanoparticle concentrations from 0.4 to $200 \mathrm{nM}$ (lanes 3-7). (b) Effect of silica nanoparticles on amplification of a $710 \mathrm{bp}$ target from PCR model 1. For all nanoparticle concentrations from 0.4 to $20 \mathrm{nM}$ (lanes 2-6), the PCR outcomes are similar to those obtained without nanoparticles (lane 1). Thus, for both PCR models, the effect of negatively charged silica nanoparticles is not significant as compared with that for citratestabilized AuNPs. The normalized quantities of PCR specificity $\left(S^{\llcorner}\right)$and efficiency $\left(E^{\llcorner}\right)$for each lane are indicated on the bottom panels. local conditions in "nanoreactor". On the other hand, it has been supposed ${ }^{30}$ that $\mathrm{Au}$ nanoparticles in PCR mixture act as small nanoreactors, in which the local concentration of primers and templates is increased owing to electrostatic interactions between AuNPs and PCR components. In this model, the particle charge is important, irrespective of the particle material. To verify these models, we fabricated silica nanospheres with the $20 \mathrm{~nm}$ size and $-31.2 \mathrm{mV}$ zeta-potential close to those for citrate-stabilized AuNPs (16 $\mathrm{nm}$ and $-29.9 \mathrm{mV}$, respectively). If the nanoparticle charge plays a crucial role, one would expect a similar PCR enhancement for both particle types. If the material heat properties are important, one would expect quite different PCR outcomes. Fig. 6 shows that the second alternative agrees with experimental data. Indeed, we observed dramatic difference in PCR results for gold and silica nanoparticles with close parameters except for their heat properties. Of course, the chemical structure and physical properties of the nanoparticle surface should also be considered for ultimate conclusions.

\section{Conclusion}

In conclusion, we have studied the effects of AuNP concentration, charge, shape and material on the PCR efficiency and specificity. For two new PCR systems that were not studied previously, we have obtained high specific and efficient enhancement of target amplicons at optimal citrate-stabilized AuNP concentration about $0.4 \mathrm{nM}$. This observation agrees with previous reports for other PCR models and confirms a universal nature of underlying enhancement mechanisms at least for citrate-stabilized AuNPs. ${ }^{29,32-36}$ Functionalization of citrate-stabilized AuNPs with neutral PVP and PEG-SH polymers results in elimination of enhancing properties, although the particle zeta-potentials remain the original sign and values. This phenomenon can be related to steric hindrance effects that prevent a proper interaction of PCR molecular components with nanoparticles. Functionalization of AuNPs with cationic polymers PDDA and CTAB leads to expected reverse of the particle charge sign. However, in contrast to previous report on positive 
enhancing properties of PDDA capped particles, we have obtained non-distinguishable enhancing effect. The particle shape plays negligible role as demonstrated by comparison of PCR outcomes with CTAB-coated gold nanospheres and nanorods. We have performed also PCR amplifications with two gold and silica particles of similar size and charge to show that the gold particles greatly enhance PCR results whereas silica counterparts do not. This implies a possible positive role of metallic heat properties in local environment of PCR nanoreactor. To summarize, further studies are needed to understand the underlying physicochemical mechanisms of nanoparticleenhanced PCR, including the role of nanoparticle size, charge, surface functionalization, and the dynamic ratio between nanoparticle concentration and concentration of PCR system components.

\section{Experimental section}

\subsection{Materials}

All chemicals were obtained from commercial suppliers and used without further purification. Cetyltrimethylammonium bromide (CTAB, >98.0\%), L-ascorbic acid (AA, >99.9\%), sodium borohydride $\left(\mathrm{NaBH}_{4}, 99 \%\right)$, tetraethyl orthosilicate (TEOS), aqua ammonia (28-30\%), L-arginine (98\%), cyclohexane (anhydrous, 99.5\%), thiolated poly(ethylene glycol) (mPEG-SH, $M_{\mathrm{w}}=$ 5000), poly(vinyl pyrrolidone) (PVP, $M_{\mathrm{w}}=55000$ ), polydiallyldimethylammonium chloride (PDDA, 20\% solution) were purchased from Sigma-Aldrich. Hydrogen tetrachloroaurate trihydrate $\left(\mathrm{HAuCl}_{4} \cdot 3 \mathrm{H}_{2} \mathrm{O}\right)$ and silver nitrate $\left(\mathrm{AgNO}_{3},>99 \%\right)$ were procured from Alfa Aesar. Absolute ethanol (ET0016, 99.99\%) was obtained from Scharlau Chemie. Sodium hydroxide $(\mathrm{NaOH})$, potassium carbonate $\left(\mathrm{K}_{2} \mathrm{CO}_{3}\right)$ and sodium chloride $(\mathrm{NaCl})$ were purchased from Reachim (Russia). Hydrochloric acid ( $\mathrm{HCl}, 37 \mathrm{wt} \%$ in water) was purchased from Vekton (Russia). Tris, $\left(\mathrm{C}_{4} \mathrm{H}_{11} \mathrm{NO}_{3}\right)$; ethylenediaminetetraacetic acid, disodium salt (EDTA); boric acid $\left(\mathrm{HBO}_{3}\right)$; LE-2 agarose (Biotechnology Grade), ethidium bromide (EtBr), were purchased from Helicon (Russia). Phosphate buffer in tablets (PB; pH 7.4), 0.01 Mwas purchased from Biolot. MassRuler Low Range DNA Ladder, $6 \times$ loading dye, Taq DNA polymerase, dNTP mix were purchased from Fermentas, ThermoFisher Scientific. Ultrapure water was obtained from a Milli-Q Integral 5 system (Millipore) and used in all experiments.

\subsection{Synthesis of nanoparticles}

Spherical AuNPs with $16 \mathrm{~nm}$ average diameter were fabricated by reduction of $\mathrm{HAuCl}_{4}$ with sodium citrate as described by Grabar et $a l^{37}$ and were used as a template for subsequent capping with various surface ligands. Briefly, $25 \mathrm{~mL}$ of $38.8 \mathrm{mM}$ sodium citrate was added quickly to boiled $250 \mathrm{~mL}$ of $1 \mathrm{mM}$ water solution $\mathrm{HAuCl}_{4}$, which resulted in a change in solution color from pale yellow to deep red.

To obtain polymer-capped AuNPs, ${ }^{38}$ the as-prepared AuNPs were mixed with appropriate amount of each surface agent such as mPEG-SH, PVP or PDDA respectively, incubated for some time with subsequent centrifugation and resuspension in MQ water. A detail description of ligand capping procedures are given in ESI file. $\dagger$

Gold nanorods (AuNRs) with length and diameter about $70 \mathrm{~nm}$ and $25 \mathrm{~nm}$, respectively, were fabricated according to Ratto et $a l .{ }^{39}$ with minor modifications. ${ }^{40}$ First, gold seed particles were prepared by adding aqueous ice-cold sodium borohydride (10 mM, $0.1 \mathrm{~mL})$ to a mixed aqueous solution of CTAB $(0.1 \mathrm{M}, 1 \mathrm{~mL})$ and $\mathrm{HAuCl}_{4}(10 \mathrm{mM}, 0.025 \mathrm{~mL})$ and were vigorously stirred for about 2 minutes. After sequential addition of 28 $\mu \mathrm{L}$ of $100 \mathrm{mM} \mathrm{AA}$ and $12 \mu \mathrm{L}$ of two-hours-aged gold seeds to a growth solution $(5 \mathrm{~mL}$ of $0.1 \mathrm{M} \mathrm{CTAB}, 250 \mu \mathrm{L}$ of $0.01 \mathrm{M}$ $\mathrm{HAuCl}_{4}$, and $100 \mu \mathrm{L}$ of $4 \mathrm{mM} \mathrm{AgNO}_{3}$ ), the mixture was incubated for $24 \mathrm{~h}$ at $25{ }^{\circ} \mathrm{C}$. Finally, $16 \mu \mathrm{L}$ of $10 \mathrm{mM}$ ascorbic acid was added in three portions every $24 \mathrm{~h}$. AuNRs were allowed to grow overnight without stirring at $30{ }^{\circ} \mathrm{C}$. Then, as-prepared AuNRs were repeatedly centrifuged and redispersed overnight in $1 \mathrm{mM}$ CTAB.

Highly monodisperse $\mathrm{SiO}_{2} \mathrm{NPs}$ with $20 \mathrm{~nm}$ TEM average diameter were synthesized following the multistep seedmediated growth technique in an aqueous solution of L-arginine. ${ }^{41}$ Briefly, $9.1 \mathrm{mg}$ of $\mathrm{L}$-arginine was added to $6.9 \mathrm{~mL}$ of water in a standard $20 \mathrm{~mL}$ scintillation vial under magnetic stirring. Then, $0.45 \mathrm{~mL}$ of cyclohexane was accurately added to the top of the solution and the mixture was heated to $60{ }^{\circ} \mathrm{C}$. Further, 0.55 $\mathrm{mL}$ of TEOS was added to the top layer of cyclohexane and the mixture was allowed to react for $20 \mathrm{~h}$. A key tip for synthesizing high-quality monodisperse $\mathrm{SiO}_{2} \mathrm{NPs}$ is to keep the cyclohexane and water parts unmixed, ensuring very slow addition of TEOS to the reaction mixture.

\subsection{Characterization}

Extinction spectra of as-prepared and ligand-capped nanoparticles solutions were measured with a Specord BS-250 and Specord S-300 spectrophotometers (Analytik, Jena, Germany). Transmission electron microscopy (TEM) images were obtained using Libra-120 transmission electron microscope (Carl Zeiss, Jena, Germany) at the Simbioz Center for the Collective Use of Research Equipment in the Field of Physical-Chemical Biology and Nanobiotechnology at the IBPPM RAS. The average diameters of as-prepared and polymer-capped AuNPs and silica nanoparticles and their zeta-potentials were measured with a Zetasizer Nano ZS device (Malvern, UK).

\subsection{DNA samples}

Model 1. A. brasilense $\mathrm{Sp} 7$ genomic DNA. Azospirillum brasilense strain Sp7 (IBPPM 150) from the Collection of Rhizosphere Microorganisms (IBPPM RAS, Saratov, Russia) ${ }^{\mathbf{4 2}}$ was used to prepare the DNA template. The target gene was a nitrogen fixation (nifD) gene for Azospirillum species (GenBank accession number: M64344 (ref. 43)). The experimental synthetic primers (Syntol, Russia) are listed in Table 2. Bacteria were cultured at $37{ }^{\circ} \mathrm{C}$ in a liquid malate-salt medium (MSM) as described previously. ${ }^{\mathbf{4 4}}$ The starting cell density of the $18 \mathrm{~h}$ cultures for DNA extraction was estimated by absorbance measurements on a Specord S-300 spectrophotometer at $660 \mathrm{~nm}$. $1 \mathrm{~mL}$ of the bacterial suspension $\left(2 \times 10^{7}\right.$ cells per $\left.\mathrm{mL}\right)$ after centrifugation 
Table 2 Oligonucleotide primers used in PCR experiments

\begin{tabular}{|c|c|c|c|c|}
\hline Primer name & Sequence $\left(5^{\prime}-3^{\prime}\right)$ & Length (bp) & Amplicon size (bp) & Ref. \\
\hline \multicolumn{5}{|c|}{ Primers used for $A$. brasilense Sp7 DNA } \\
\hline nifD-up & GAGGCTATTCGGCTATGACTG & 21 & 710 (sample 1) & 43 \\
\hline \multicolumn{5}{|c|}{ Primers used for C. trachomatis DNA } \\
\hline momp-fw1 & TTCAATTTAGTTGGATTGTTTGG & 23 & 157-160 (sample 2) & 45 \\
\hline momp-rv1 & CACATTCCCAGAGAGCTGC & 19 & & \\
\hline momp-rv2 & CACATTCCCACAAAGCTGC & 19 & & \\
\hline momp-rv3 & CGGACTCCCACAAAGCTGC & 19 & & \\
\hline momp-rv4 & GCACTCCCACAAAGCTGC & 18 & & \\
\hline F1 & CGGTATTAGTATTTGCCGCTTTG & 23 & 1156 (sample 3) & 46 \\
\hline B11 & CGGAATTGTGCATTTACGTGAG & 22 & & \\
\hline
\end{tabular}

(Minispin, Eppendorf) at $5000 \mathrm{~g}$ for $10 \mathrm{~min}$ was suspended in TE buffer (Tris HCl, $10 \mathrm{mM}$, EDTA, $1 \mathrm{mM}$ ). A genomic DNA purification kit (Thermo Scientific, Lithuania) was used for DNA extraction following the manufacturer's instruction. The kit is based on selective detergent-mediated DNA precipitation of crude lysate from different sample sources, including bacterial cells. The extracted DNA samples were further resuspended into $100 \mu \mathrm{L}$ of MQ water. The extracted DNA concentration and purity were estimated by UV-spectrophotometry on a Specord BS-250 spectrophotometer by $A_{260} / A_{280}$ and $A_{260} / A_{230}$ ratio, respectively, as indicative of nucleic acids purity $\left(A_{260} / A_{280} \geq 1.8\right.$ and $\left.A_{260} / A_{230}=2\right) .{ }^{4}$ DNA quality was examined in $1 \%$ agarose gel electrophoresis. The DNA samples were stored at $-20{ }^{\circ} \mathrm{C}$ until use in PCR.

Model 2 and model 3. C. trachomatis genomic DNA. The autoclaved C. trachomatis positive DNA from clinical samples (C. trachomatis DNA) were received from FSBSI Saratov SRVI, the Department Zoo- and Zoo-anthroponotic diseases and were used as DNA templates without further purification. The target was chromosomal ompA gene of C. trachomatis genovars (GenBank accession numbers: M58938, DQ064281, AF352789, AF063196, AY535104 (ref. 45 and 46)). The experimental synthetic primers (Syntol, Russia) are listed in Table 2. The DNA samples were stored at $-20{ }^{\circ} \mathrm{C}$ until use in PCR.

\subsection{PCR and gel electrophoresis}

All PCR reactions were conducted in triplicate with a T-100 Thermal Cycler (Bio-Rad, USA). PCR reagents were mixed to a final $30 \mu \mathrm{L}$ reaction volume in $200 \mu \mathrm{L}$ thin-walled tubes (Scientific Specialties, Inc., USA). Full PCR mixture in absence of nanoparticles was used as blank in all experiments. Pure double-distilled water (PCR-grade) as template was used for negative control in all experiments.

Each PCR tube with sample 1 DNA (A. brasilense Sp7) as a template contained: $3 \mu \mathrm{L} 10 \times$ PCR buffer, $0.6 \mu \mathrm{L} 10 \mathrm{mM}$ dNTPs, $3 \mu \mathrm{L} 25 \mathrm{mM} \mathrm{MgCl}_{2}, 0.5 \mu \mathrm{L} 5 \mathrm{U} \mu \mathrm{L}^{-1}$ Taq DNA polymerase, $2 \mu \mathrm{L}$ template containing 120-200 ng DNA, $50 \mathrm{pmol}$ of each primer $(0.3 \mu \mathrm{L}$ nifD-up and $0.3 \mu \mathrm{L}$ nifD-do primer), and 15 $\mu \mathrm{L}$ of appropriate NPs (varying in concentrations and particle type) and filled up to the $30 \mu \mathrm{L}$ final volume with MQ water. The PCR procedure was as follows: $5 \mathrm{~min}$ at $94{ }^{\circ} \mathrm{C}$ for predenaturation, followed by 35 cycles of $30 \mathrm{~s}$ at $94{ }^{\circ} \mathrm{C}, 30 \mathrm{~s}$ at $52{ }^{\circ} \mathrm{C}$, and $30 \mathrm{~s}$ at $72{ }^{\circ} \mathrm{C}$. Then the cycling was terminated after 10 min final elongation step at $72{ }^{\circ} \mathrm{C}$.

Each PCR tube with sample 2 DNA (C. trachomatis) as a template contained: $3 \mu \mathrm{L} 10 \times$ PCR buffer, $0.6 \mu \mathrm{L} 10 \mathrm{mM}$

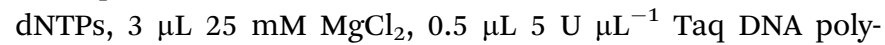
merase, $2 \mu \mathrm{L}$ template containing 120-200 ng DNA, a multiplexbroad-spectrum PCR primer mix containing $1 \mu \mathrm{L}$ multiple forward primer (equimolar mix of 10 pmol momp-fw1, mompfw2, momp-fw3) and 1.2 $\mu \mathrm{L}$ multiple reverse primer (equimolar mix of 10 pmol momp-rv1, momp-rv2, momp-rv3, momprv4), and $15 \mu \mathrm{L}$ of appropriate NPs (varying in concentrations and particle type) and filled up to the $30 \mu \mathrm{L}$ final volume with MQ water. The PCR procedure was as follows: 2 min preheating step at $94{ }^{\circ} \mathrm{C}$ followed by 38 cycles of amplification $\left(30 \mathrm{~s}\right.$ at $94{ }^{\circ} \mathrm{C}$, $30 \mathrm{~s}$ at $55^{\circ} \mathrm{C}$, and $30 \mathrm{~s}$ at $72{ }^{\circ} \mathrm{C}$ ) and a final 10 min elongation step at $72{ }^{\circ} \mathrm{C}$. Purified DNA of genovar E as a template was used as positive control in all experiments.

Each PCR tube with sample 3 DNA (C. trachomatis) as a template contained: $3 \mu \mathrm{L} 10 \times$ PCR buffer, $0.6 \mu \mathrm{L} 10 \mathrm{mM}$ dNTPs, $1.8 \mu \mathrm{L} 25 \mathrm{mM} \mathrm{MgCl}_{2}, 0.15 \mu \mathrm{L} 5 \mathrm{U}^{-1}$ Taq DNA polymerase, $1 \mu \mathrm{L}$ template containing 120-200 ng DNA, $50 \mathrm{pmol}$ of each primer ( $1 \mu \mathrm{L} \mathrm{F1}$ and $1 \mu \mathrm{L}$ B11), and $15 \mu \mathrm{L}$ of AuNPs in serial dilutions and filled up to the $30 \mu \mathrm{L}$ final volume with MQ water. The PCR procedure was as follows: 2 min preheating step at $92{ }^{\circ} \mathrm{C}$ followed by 35 cycles of amplification $\left(45 \mathrm{~s}\right.$ at $94^{\circ} \mathrm{C}, 45 \mathrm{~s}$ at $55{ }^{\circ} \mathrm{C}$, and $60 \mathrm{~s}$ at $72{ }^{\circ} \mathrm{C}$ ) and a final $10 \mathrm{~min}$ elongation step at $72{ }^{\circ} \mathrm{C}$. Purified DNA of genovar E as a template was used as positive control in all experiments.

After the PCR amplification, all the samples were stored at $4{ }^{\circ} \mathrm{C}$ before gel-electrophoresis. The PCR products were analyzed by horizontal electrophoresis system (SE 1, Helicon) with a voltage set at $125 \mathrm{~V}$ for $65 \mathrm{~min}$ (Elf-4 power supplier, DNAtechnology) with EtBr staining. Briefly, $3.5 \mu \mathrm{L}$ of each PCR product was mixed with $0.5 \mu \mathrm{L} 6 \times$ loading dye prior to loading in the wells of an $1.5 \%$ agarose gel with EtBr containing in $1 \times$ TBE buffer (10 mM Tris, $10 \mathrm{mM}$ boric acid, 1 mM EDTA, pH 8.0). 
The fluorescence of the bands was visualized by UV transillumination (312 nm, Vilber Lourmart), the gel electrophoregrams were obtained with a Canon 350D digital camera equipped with an orange filter to minimize the UV-lamp background lighting.

\subsection{PCR product quantification}

The performance of PCR additives was quantified according to recent report $^{30}$ through calculations of two densitometric quantities, which are termed specificity and yield efficiency. The gel electrophoregram images were analyzed with an open Image J software and the output data were represented as the means and standard deviations $(n=3)$. A detail description of calculations is given in ESI file. $\dagger$ In brief, the ratio of the densitometric value of the specific target band to that of all bands amplified by PCR was defined as the specificity of amplification. By this definition, if there are no smears in PCR products, the maximal value of specificity equals 1 . The ratio of the densitometric intensity of a specific target band to that for $500 \mathrm{bp}$ of DNA marker was used as a measure of the yield efficiency. For brevity, we use the term "efficiency". If the obtained efficiency is $\geq 1$, the PCR additive is considered as high efficient for PCR optimization. In all figures, molecular weight markers (M) represented the same SM0383 (ThermoFisher Scientific). The optimal concentration of PCR additives was defined as a concentration that maximizes the brightest of specific target band.

\section{Acknowledgements}

This work was supported the Russian Scientific Foundation (project No. 14-13-01167). The work by TEP (PCR amplification) was partially supported by Bortnik Foundation grant U. M. N. I. K. (project No. 11736 p/17259). The work by VAK (synthesis of silica nanoparticles) was partially supported by RFBR grant (project No. 16 52-45026). We thank Drs V. A. Bogatyrev, L. A. Dykman and B. N. Khlebtsov for helpful discussion, Dr A. M. Burov for TEM experiments, A. A. Budanova and Dr A. A. Shirokov for providing the Azospirillum brasilense Sp7 cells and help in the DNA extraction experiments, Dr T. I. Polyanina and Yu. Saltykov for providing the specimen from clinical samples.

\section{Notes and references}

1 R. K. Saiki, D. H. Gelfand, S. Stoffel, S. J. Scharf, R. Higuchi, G. T. Horn, K. B. Mullis and H. A. Erlich, Science, 1988, 239, 487.

2 J. Lu, H. Li, H. An, G. Wang, Y. Wang, M. Li, Y. Zhang and J. Hu, J. Am. Chem. Soc., 2004, 126, 11136.

3 C. Ding and C. R. Cantor, Proc. Natl. Acad. Sci. U. S. A., 2003, 100, 7449.

4 J. Sambrook and D. W. Russell, Molecular Cloning: A Laboratory Manual, Cold Spring Harbor Laboratory Press, Cold Spring Harbor, 3rd edn, 2001.

5 W. Henke, K. Herdel, K. Jung, D. Schnorr and S. A. Loening, Nucleic Acids Res., 1997, 25, 3957.
6 M. Nagai, A. Yoshida and N. Sato, Biochem. Mol. Biol. Int., 1998, 44, 157.

7 P. Winship, Nucleic Acids Res., 1989, 17, 1266.

8 Q. Chou, Nucleic Acids Res., 1992, 20, 4371.

9 P. Belgrader, W. Benett, D. Hadley, G. Long, R. Mariella Jr, F. Milanovich, S. Nasarabadi, et al., Clin. Chem., 1998, 44, 2191-2194.

10 C. T. Wittwer, K. M. Ririe, R. V. Andrew, D. A. David, R. A. Gundry and U. J. Balis, BioTechniques, 1997, 22, 176181.

11 K. H. Roux, Genome Res., 1995, 4, S185-S194.

12 S. Ekman, Lichenologist, 1999, 31, 517-531.

13 K. H. Hecker and K. H. Roux, BioTechniques, 1996, 20, 478485.

14 R. T. D'Aquila, L. J. Bechtel, J. J. Videler, J. J. Eron, P. Gorczyca and L. C. Kaplan, Nucleic Acids Res., 1991, 19, 3749.

15 H. A. Erlich, D. Gelfand and J. J. Sninsky, Science, 1991, 252, 1643-1651.

16 M. Rabodonirina, L. Cotte, A. Boibieux, K. Kaiser, M. Mayencon, D. Raffenot, C. Trepo, D. Peyramond and S. Picot, J. Clin. Microbiol., 1999, 37, 127.

17 R. Don, P. Cox, B. Wainwright, K. Baker and J. Mattick, Nucleic Acids Res., 1991, 19, 4008.

18 X. Lou and Y. Zhang, ACS Appl. Mater. Interfaces, 2013, 5, 6276-6284.

19 J. Jia, L. Sun, N. Hu, G. Huang and J. Weng, Small, 2012, 8, 2011-2015.

20 L. Ma, S. He, J. Huang, L. Cao, F. Yang and L. Li, Biochimie, 2009, 91, 969-973.

21 S.-H. Hwang, S.-G. Im, S. S. Hah, V. T. Cong, E. J. Lee, Y.-S. Lee, G. K. Lee, D.-H. Lee and S. J. Son, PLoS One, 2013, 8, e73408.

22 Y. Liang, F. Luo, Y. Lin, Q. Zhou and G. Jiang, Carbon, 2009, 47, 1457-1465.

23 R. M. Williams, S. Nayeem, B. D. Dolash and L. J. Sooter, PLoS One, 2014, 9, e94117.

24 Z. Z. Zhang, M. C. Wang and H. J. An, Nanotechnology, 2007, 18, 355706 .

25 H. B. Shen, M. Hu, Y. B. Wang and H. Q. Zhou, Biophys. Chem., 2005, 115, 63-66.

26 L. Wang, Y. Zhu, Y. Jiang, R. Qiao, S. Zhu, W. Chen and C. Xu, J. Phys. Chem. B, 2009, 113, 7637-7641.

27 A. Khaliq, P. J. Sonawane, B. K. Sasi, B. S. Sahu, T. Pradeep, S. K. Das and N. R. Mahapatra, Nanotechnology, 2010, 21, 255704.

28 W. X. Y. Cao, X. Y. Shi, W. C. Yang, X. D. Zhang, C. H. Fan and J. Hu, Analyst, 2009, 134, 87-92.

29 H. Li, J. Huang, J. Lv, H. An, X. Zhang, Z. Zhang, C. Fan and J. Hu, Angew. Chem., 2005, 44, 5100-5103.

30 L. Yuan and Y. He, Analyst, 2013, 138, 539-545.

31 D. Cui, F. Tian, Y. Kong, I. Titushikin and H. Gao, Nanotechnology, 2004, 15, 154-157.

32 M. Li, Y.-C. Lin and C.-C. Wu, Nucleic Acids Res., 2005, 33, e184.

33 A. Li, B. Zhou, C. S. Alves, B. Xu, R. Guo, X. Shi and X. Cao, ACS Appl. Mater. Interfaces, 2016, 8, 25808-25817. 
34 S. Dabrowski, M. Olszewski, R. Piatek, A. BrillowskaDabrowska, G. Konopa and J. Kur, Microbiology, 2002, 148, 3307-3315.

35 A. L. Haber, K. R. Griffiths, A. K. Jamting and K. R. Emslie, Anal. Bioanal. Chem., 2008, 392, 887-896.

36 B. V. Vu, D. Litvinov and R. C. Willson, Anal. Chem., 2008, 80, 5462-5467.

37 K. C. Grabar, R. G. Freeman, M. B. Hommer and M. J. Natan, Anal. Chem., 1995, 67, 735-743.

38 K. Aslan and V. H. Pérez-Luna, Langmuir, 2002, 18, 60596065.

39 F. Ratto, P. Matteini, F. Rossi and R. Pini, J. Nanopart. Res., 2010, 12, 2029.

40 T. E. Pylaev, V. A. Khanadeev, B. N. Khlebtsov, L. A. Dykman, V. A. Bogatyrev and N. G. Khlebtsov, Nanotechnology, 2011, 22, 285501.
41 K. D. Hartlen, A. P. T. Athanasopoulos and V. Kitaev, Langmuir, 2008, 24, 1714-1720.

42 http://collection.ibppm.ru/.

43 D. P. Potrich, L. M. Passaglia and I. S. Schrank, Braz. J. Med. Biol. Res., 2001, 34, 1105-1113.

44 J. Döbereiner and J. M. Day in Intern. Symp. Nitrogen Fixation - Interdisciplinary Discussion, 1976, pp. 518-538.

45 K. D. Quint, L. J. Van Doorn, B. Kleter, M. N. C. De Koning, H. A. M. Van Den Munckhof, S. A. Morre, B. Ter Harmsel, E. Weiderpass, G. Harbers, W. J. G. Melchers and W. G. V. Quint, J. Mol. Diagn., 2007, 9, 631-638.

46 D. Dean, E. Oudens, G. Bolan, N. Padian and J. Schachter, J. Infect. Dis., 1995, 172, 1013-1022. 